Enéas Ricardo Konzen ${ }^{1+}$, Marcio Carlos Navroski', Mariane de Oliveira Pereira², Bruno Nascimento', Aline Meneguzzi', Patrícia Fukushima de Souza'

\title{
GENETIC VARIATION FOR GROWTH VARIABLES OF Eucalyptus benthamii MAIDEN \& CAMBAGE AND E. smithii R. T. BAKER PROVENANCES IN SOUTHERN BRAZIL
}

Keywords:

Provenance trial

Genetic variation

Selection

Heritability

Historic:

Received 08/05/2017

Accepted 06/09/2017

Palavras chave:

Teste de procedências

Variação genética Seleção

Herdabilidade

+Correspondence: erkonzen@gmail.com

DOI:
ABSTRACT: Southern Brazil encompasses areas with a subtropical climate, with significant number of frosts, which challenge or even impair growing tropical eucalypts. Eucalyptus benthamii and E. smithii rise as alternative species of subtropical origin with considerable frost-tolerance. Here we accessed the genetic variation for diameter at breast height $(D B H)$, height $(H)$, volume $(V O L)$, bifurcation and straightness of four provenances of $E$. smithii and two of $E$. benthamii, cultivated in randomized block design in a farm in Rio Negrinho, Santa Catarina, southern Brazil. We found considerable genetic variability for the traits, all directly associated with the selection for wood production and quality. In general, most of the genetic variability was found within the provenances $\left(Q_{d}\right.$ ranged from 63.6 to $\left.73.1 \%\right)$, except for straightness $\left(Q_{d}=13.5 \%\right.$ and $\left.Q_{s t}=81.9 \%\right)$. Although predicting genetic gains with provenance trials might have some drawbacks, the application of the REML/BLUP method was able to predict genetic gains for the growth variables $D B H, H$ and VOL for provenances of the two species. The highest genetic gains were predicted for a provenance of $E$. smithii originated from Australia ( $13 \%$ for $\mathrm{DBH}, 5 \%$ for $\mathrm{H}$ and $6.1 \%$ for VOL). However, the genetic gains from a $E$. benthamii provenance from Santa Catarina state were not negligible (I.2\% for $\mathrm{DBH}, \mathrm{I} .8$ for $\mathrm{H}$ and $2.2 \%$ for $\mathrm{VOL}$ ). Our results provide insights for further progeny trials aimed at investigating additive genetic variance and their components, which could improve the genetic control of the traits and assist breeding programs of $E$. smithii and $E$. benthamii.

\section{VARIAÇÃO GENÉTICA PARA VARIÁVEIS DE CRESCIMENTO DE PROCEDÊNCIAS DE Eucalyptus benthamii MAIDEN \& CAMBAGE E E. smithii R. T. BAKER DO SUL DO BRASIL}

RESUMO: O Sul do Brasil apresenta áreas com clima subtropical, com número significativo de geadas, que dificultam ou, até mesmo, impossibilitam o crescimento de eucaliptos tropicais. Eucalyptus benthamii e $E$. smithii surgem como espécies alternativas de origem subtropical com considerável tolerância a geadas. Estudou-se a variação genética para diâmetro a altura do peito $(D A P)$, altura $(H)$, volume $(V O L)$ e tortuosidade em quatro procedências de Eucalyptus smithii e duas de $E$. benthamii, plantadas em delineamento em blocos casualizados em área experimental do município de Rio Negrinho, Santa Catarina, sul do Brasil. Foi encontrada variabilidade genética considerável para os caracteres investigados, todos diretamente associados com a seleção para produção e qualidade da madeira. Em geral, a maior proporção da diversidade genética foi encontrada dentro das procedências $\left(Q_{d}\right.$ variou de 63,6 a $\left.73, \%\right)$, exceto para tortuosidade $\left(Q_{d}=13,5 \%\right.$ e $\left.Q_{s t}=81,9 \%\right)$. Embora a predição de ganhos genéticos com testes de procedências apresente limitações, o emprego do método REML/ BLUP permitiu predizer ganhos genéticos para as variáveis $D A P, H$ e VOL nas procedências e indivíduos das duas espécies. Os ganhos genéticos mais elevados foram preditos para uma procedência de $E$. smithii originária da Austrália (I $3 \%$ para DAP, $5 \%$ para $H$ e $6,1 \%$ para VOL). Contudo, os ganhos genéticos potenciais com a procedência de $E$. benthamii de Santa Catarina não foram negligenciáveis ( I,2\% para DAP, I,8\% para $\mathrm{H}$ e 2,2\% para VOL). Estes resultados representam importantes contribuições para a realização de testes de progênies posteriores para investigar a variação genética aditiva e seus componentes, o que pode aprimorar o conhecimento do controle genético dos caracteres e auxiliar no desenvolvimento de programas de melhoramento genético de $E$. smithii e E. benthamii.

' University of the State of Santa Catarina - Lages, Santa Catarina, Brazil

${ }^{2}$ Federal University of Paraná - Curitiba, Paraná, Brazil 


\section{INTRODUCTION}

Eucalypts were introduced from Australia and surrounding islands to Brazil in the early twentieth century. Their rapid growth and high productivity as well as adaptability to Brazilian climates and soils were perceived as an outstanding opportunity for their cultivation in the country (MORA e GARCIA, 2000). The public investments toward reforestation in the 1960's promoted a rapid expansion of eucalypts plantations in Brazil (ODA et al., 2007; FONSECA et al., 20I0). Breeding strategies coupled with the development of efficient methods for the clonal propagation of elite genotypes have dramatically increased the productivity of species of Eucalyptus and Corymbia in the country (ODA et al., 2007). Recent data showed a total area of 5.6 millions hectares planted with eucalypts, $72 \%$ of the total forest plantations (IBA, 2016). The plantations have been dedicated to several industry purposes, including paper and cellulose, charcoal, panels and civil construction (ABRAF, 20I3; IBA, 20I6).

The majority of the production of eucalypts in Brazil, however, has been with E. grandis and E. urophylla. An estimate of $80 \%$ of the entire production involves the hybrid between $E$. grandis and $E$. urophylla, commonly referred as "urograndis". Several clones have been developed by companies or public institutions and are continuously genetically improved in breeding programs (FONSECA et al., 20I0). However, the performance of such species or the hybrid varies according to the region they are planted, as a result of strong genotype $x$ environment interaction (MORI et al., 1988; Santos et al., 1990; ROCHA et al., 2005; SANTOS et al., 2016).

To circumvent environmental issues as well as introducing new genetic variability, alternative eucalypt species have been tested in different locations in Brazil and other countries (ALMEIDA-AZEVEDO et al., 2015; SANTOS et al., 2015; COSTA et al., 2016; ENGEL et al., 2016). Whether as single species or hybrid combinations, considering the natural proclivity for hybridization among determined taxa of Eucalyptus or Corymbia, plantations of alternative species are accounting for the total area of eucalypts produced (IBÁ, 20I6).

Southern Brazil encompasses areas with subtropical climates ( $\mathrm{Cfa}$ and $\mathrm{Cfb}$, according to Koppen's categorization) (ALVARES et al., 20I3), where average annual temperatures are around or below $22^{\circ} \mathrm{C}$. The elevated areas of the states of Santa Catarina, Rio Grande do Sul and Paraná have considerable number of frost events, which affect the cultivation of eucalypts with low cold tolerance. Therefore, introducing species with lowtemperature tolerance or even hybrid combinations such as urograndis with the alternative species is important to increase the production of eucalypts in colder regions.
Eucalyptus smithii and $E$. benthamii have risen as potential alternatives for cultivation in Southern Brazil. E. smithii is native to northeastern Victoria and southeastern New South Whales, Australia (FONSECA et al., 20I0). The species is distributed in temperate and subtropical climates, with temperatures of the warmest months varying from 23 to $28{ }^{\circ} \mathrm{C}$ and of the coldest months between -2 and $6^{\circ} \mathrm{C}$. The annual precipitation varies from 750 to $1700 \mathrm{~mm}$ and is evenly distributed over the year (Boland et al., 1992). The species is described as cold-tolerant, and studies have also suggested higher drought-tolerance in comparison to other species such as E. globulus (MITCHELL et al., 20I2). In turn, E. benthamii is distributed in a limited area southwest of Sydney, New South Whales. The species is well adapted to diverse sites and environments with average maximum temperatures between 27 and $29^{\circ} \mathrm{C}$ in summer. In winter, the average minimum temperatures are between 2 and $3{ }^{\circ} \mathrm{C}$. Originally, the species occurred in fertile soils of alluvial floodplains in an area of $100 \mathrm{~km}$ in length and $40 \mathrm{~km}$ large around the Nepean river (Benson, 1985; Butcher et al., 2005). In Brazil, both species are better adapted to the South, presenting considerable tolerance to frosts (FONSECA et al., 20I0; BACCARIN et al., 20I5).

E. benthamii and E. smithii breeding are still at initial stages, considering the recent investments with their plantation. Therefore, it is important to select provenances and progenies that might be potentially employed in further stages of breeding. Species and provenance tests provide the genetic base for the selection of genetic materials of superior quality for the most diverse applications, implicating in genetic gains from the beginning of the tests. Considering that these species were introduced, such tests will compose base populations for producing seeds for progeny trials or rescuing potential matrices for their clonal propagation.

Our study was devoted to the evaluation of a provenance and species trial planted in southern Brazil. We evaluated growth variables of fours provenances of E. smithii and two provenances of E. benthamii. An analysis of genetic variance components of the genetic materials allowed the identification of genetically superior genotypes. Moreover, potential genetic gains were predicted from the selection of the best provenances. Such results are supportive of further steps of breeding programs with the two species.

\section{MATERIAL AND METHODS}

\section{Location of the experiment}

The provenance and species test evaluated in this study was planted in 1999 in Rio Negrinho municipality, 
state of Santa Catarina, Southern Brazil. The area is located at an average altitude of $791 \mathrm{~m}$. The climate of is of type Cfb, according to Koppen's. An updated categorization of Brazilian climates showed that this area presents average annual temperature range between 15 and $17^{\circ} \mathrm{C}$ (ALVARES et al., 20I3). The annual average precipitation is $1,720 \mathrm{~mm}$ (EPAGRI/CIRAM, 2009).

The soils of the experimental area comprise cambisols and podzols with the following attributes:

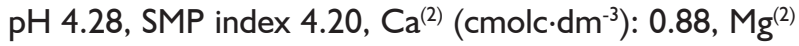
$\left(\mathrm{cmolc} \cdot \mathrm{dm}^{-3}\right): 0.76, \mathrm{Al}^{(2)}\left(\mathrm{cmolc} \cdot \mathrm{dm}^{-3}\right): 4.64, \mathrm{P}^{-3 e h l i c h}{ }^{(2)}$ $\left(\mathrm{mg} \cdot \mathrm{dm}^{-3}\right): 0.72, \mathrm{~K}^{(2)}\left(\mathrm{mg} \cdot \mathrm{dm}^{-3}\right): 73.80, \mathrm{MO}(\%): 3.45$, effective CEC (cmolc. $\left.\mathrm{dm}^{-3}\right): 6.46$, CEC pH $7.0\left(\mathrm{cmolc} \cdot \mathrm{dm}^{-3}\right): 36.32$, base saturation(\%): 5.00, Al saturation (\%): 7I.84, clay $\left(\mathrm{g} \cdot \mathrm{kg}^{-1}\right): 18.50$ (WEGNAR, 2000).

\section{Description of the provenances}

The experiment encompassed several species and provenances, from which were selected four provenances of $E$. smithii and two of $E$. benthamii, according to the descriptions in Table I. The genetic materials were grown from seeds.

TABLE I Species and provenances evaluated for genetic variance components..

\begin{tabular}{cccc}
\hline Species & Provenance & $\begin{array}{c}\text { Number of } \\
\text { individuals (adults) }\end{array}$ \\
\hline \multirow{3}{*}{ E. smithii } & I & Papel e Celulose Santa & 34 \\
& 2 & Catarina (P.C.C.-SC) & 17 \\
& 3 & Taboaganda & 44 \\
& 4 & Wilson Promontralia & 23 \\
\hline \multirow{3}{*}{ E. benthamii } & I & Total Australia & 118 \\
& 2 & Catarina (P.C.C.-SC) & 48 \\
& & Australia & 41 \\
& & & 89 \\
\hline
\end{tabular}

\section{Experimental design and variables evaluated}

The experiment was planted with spacing $3 \times 2 \mathrm{~m}$ and organized in completely randomized blocks with three replicates. Each line of planting was composed by one species/provenance. Each line was constituted by 45 trees.

Our work was devoted to evaluate growth variables as an initial step toward selection of superior genetic materials. The performance of the provenances was evaluated according to their survival (\%), which was reflected on the number of individuals described in Table $\mathrm{I}$, diameter at breast height $(\mathrm{DBH}, \mathrm{cm})$, height $(\mathrm{H}, \mathrm{m})$ and volume (VOL, $\mathrm{m}^{3} \cdot$ ind $\left.^{-1}\right)$. Volume was measured with a non-destructive method, as the experiment was aimed at selecting superior genotypes for breeding programs. Therefore, trees were cubed according Smalian's method with Criterion RDI000 dendrometer. The bifurcation (presence of forks) of the trunks was evaluated based on a binary scale, with 0 indicating no bifurcation and I with the presence of forks. The degree of straightness (or level of tortuosity) was graded with the following scale: I (erect trunk), 2 (slightly tortuous) and 3 (tortuous).

\section{Analysis of variance and genetic divergence components}

The data were first checked for their adjustment to the normal distribution (Shapiro Wilk test, $P<0.05$ ) and variance homogeneity (Bartlett test, $P<0.05$ ), being accordingly transformed with Box Cox when necessary. An analysis of variance (ANOVA) was performed to check for significant differences among provenances and species evaluated according to the model, where $Y_{i j k l}$ is the phenotypic value of the $I_{t h}$ individual of the $j_{t h}$ provenance of the $i_{t h}$ species of the $k_{t h}$ replicate; $m$ is the general mean; $b_{k}$ is the fixed effect of the $k_{t h}$ replicate; $t_{i}$ is the fixed effect of the $i_{t h}$ species; $f_{i j}$ is the fixed effect of the $j_{t h}$ provenance of the $i_{t h}$ species; $(t b)_{i k}$ and $(f b)_{i j k}$ are the interaction effects, and $e_{i j k l}$ is the residual.

$Y_{i j k}=m+b_{k}+t_{i}+f_{i j}+(t b)_{i k}+(f b)_{i j k}+e_{i j k l}$

The analysis was performed using the command line VARCOMP from SAS 9.4 (SAS Institute Inc.) due to the unequal number of provenances within each species and the number of trees per provenances (unbalanced experiment). The analysis of variance of each factor and their expectations are shown in Table 2. Complementary tests for mean comparisons were performed with Tukey's $(P<0.05)$. The R package "laercio" was used to compute the statistics (SILVA, 20I5).

TABLE 2 Analysis of variance for each trait at the levels of species and provenances (fixed effects).

\begin{tabular}{ccc}
\hline Variation source & DF & MS \\
\hline Blocks & $K-$ I & $\mathrm{QM}_{1}$ \\
Species (S) & $I-I$ & $\mathrm{QM}_{2}$ \\
Provenances $(\mathrm{P})$ & $\mathrm{J}-\mathrm{I}$ & $\mathrm{QM}_{3}$ \\
Residual & $(I J)(K-I)$ & $\mathrm{QM}_{4}$ \\
Total & $I J K-I$ & - \\
\hline
\end{tabular}

$\varphi(\mathrm{S})=(1 / I-1) \Sigma \mathrm{isi}^{2} ; \varphi(\mathrm{P})=(1 / J-1) \Sigma \mathrm{jpj}^{2}$

From the ANOVA, we derived the following genetic variance components: genetic variance among species $\left(\emptyset_{\varepsilon}^{2}\right)$; the genetic variance among provenances within species $\left(\varnothing_{p(e)}^{2}\right)$; and the variance of the interaction between blocks and provenances within species $\left(\sigma_{d}^{2}\right)$. From those components were estimated the genetic 
divergence among species $\left(Q_{s t}\right)$, the genetic divergence among provenances within species $\left(Q_{p}\right)$ and the genetic divergence within provenances $\left(Q_{d}\right)$, according to Souza et al. (2016).

$Q_{s t}=\frac{\theta_{e}^{2}}{\sigma_{d}^{2}+\theta_{p(e)}^{2}+\theta_{e}^{2}}$

$Q_{p}=\frac{\theta_{p(e)}^{2}}{\sigma_{d}^{2}+\theta_{p(e)}^{2}+\theta_{e}^{2}}$

$Q_{d}=1-Q_{s t}-Q_{p}$

\section{Genetic mean and variance components with REML/BLUP}

Genetic mean and variance components of the provenances were computed with Selegen (RESENDE, 2007), based on model 24, for experiments with randomized blocks of provenance and species trials with various plants per plot. The analysis was performed with REML/BLUP model for individuals and provenances. The statistical model assumed for determining the genetic variance components, where: $y$ is the data vector; $r$ is the vector of the effects of the replicates (assumed as fixed) added to the general mean; $g$ is the vector of genotypic effects (random); $p$ is the vector for plot effect; and e is the vector for the residuals (random). $X, Z$ and $W$ represent the incidence matrices for each effect.

$y=X r+Z g+W p$

The analysis generated estimates of the following genetic parameters: $V_{g}$ : genetic variation among provenances; $V_{\text {plot }}$ : environmental variation among plots $V_{\mathrm{e}}$ : environmental variation among plots; $V_{f}$ individual phenotypic variance; $h_{g}^{2}$ : determination coefficient of the effects of provenances; $C^{2}$ plot : determination coefficient of plot effect; $h_{m p}$ : average heritability of provenances and $A c_{\text {prov }}$ : selection accuracy. The genetic gains were predicted based on individual trees, as well as each provenance.

\section{RESULTS}

\section{Analysis of variance and genetic divergence}

The analysis of variance suggested significant differences $(P<0.05)$ among the provenances of $E$. benthamii and $E$. smithii for diameter at breast height $(D B H)$, height $(H)$, volume $(V O L)$ and straightness (Table 3). Bifurcation, however, was not different among the provenances (Table 3). At the level of species, bifurcation and tortuosity presented significant differences $(P<0.0 \mathrm{I})$ among $E$. benthamii and $E$. smithii. The precision of the experiment, as evaluated from the coefficient of variation, varied in each species and for the joint analysis (Table 3). The values of $\mathrm{CV}(\%)$ ranged from 10 to $40.6 \%$.

The average values of each variable are graphically represented in Figure I. The average diameter of breast height $(D B H)$ varied from $26.4 \mathrm{~cm}$ (provenance 3, Australia) to $36.7 \mathrm{~cm}$ (provenance 4, Australia) among the E. smithii provenances, while in E. benthamii population it ranged from 27.3 (Australia) to $30.5 \mathrm{~cm}$ (Papel e Celulose Santa Catarina). The lowest average height $(H=34.9 \mathrm{~cm})$ and the highest $(H=39.9 \mathrm{~cm})$ matched the same provenances of $E$. smithii, as well as of $E$. benthamii (from 35.1 to $37.7 \mathrm{~cm}$ ). Therefore, the lowest and highest volumes (VOL) also matched the same provenances of $E$. smithii, ranging from 1.779 to 2.102 $\mathrm{m}^{3}$, and of $E$. benthamii, ranging from I.792 to I.96I $\mathrm{m}^{3}$. After ANOVA, mean comparisons (Tukey's) were performed within each species and between them, as represented in Figure I.

Bifurcation was evaluated according to a binary code (I for presence and 0 for absence). In total, 12\% of the E. smithii individuals presented bifurcation, while only I individual (I.I\%) of E. benthamii was bifurcated. Provenance 3 (Australia) presented the highest number of bifurcated individuals from the $E$. smithii provenances.

TABLE 3 Summary of analysis of variance (ANOVA) and genetic divergence partition for diameter at breast height (DBH), height $(H)$, volume $(V O L)$, bifurcation and straightness (or level of tortuosity) of provenances of $E$. benthamii and $E$. smithii installed in Southern Brazil.

\begin{tabular}{|c|c|c|c|c|c|c|}
\hline Source of variation & DF & $D B H$ & $H$ & VOL & Bifurcation & Straightness \\
\hline Blocks & 2 & 422.930 & 1372.100 & 0.021 & 0.044 & 0.008 \\
\hline Species & I & 460.420 & 2079.620 & 0.060 & $0.588^{*} *$ & $7.845^{* *}$ \\
\hline Provenances & 4 & $1850.43^{* * *}$ & II 4624* & $4.57 I^{*}$ & 0.109 & $0.219 *$ \\
\hline Residual & 199 & 580.740 & 36596.000 & 1.440 & 0.064 & $0.07 I$ \\
\hline CV (\%) & - & 40.6 & 19.1 & 23.7 & 10.0 & 38.7 \\
\hline$Q_{s t}$ & - & 0.000 & 0.000 & 0.000 & 0.289 & 0.819 \\
\hline$Q_{p}$ & - & 0.269 & 0.273 & 0.277 & 0.075 & 0.047 \\
\hline$Q_{d}$ & - & 0.731 & 0.727 & 0.723 & 0.636 & 0.135 \\
\hline
\end{tabular}

Significance levels representation: ns for non-significant; * for $P<0.05$; ** for $P<0.01$. Significant values indicate differences among provenances or between the species. $Q_{s t}$ : genetic divergence among species; $Q_{p}$ : genetic diversity among provenances within species; $Q d$ : genetic divergence within provenances. 
Considering the low variability for this traits, it was excluded from the genetic and environmental variance analyses.

Straightness was scored with the numbers I (erect trunk), 2 (slightly tortuous) and 3 (tortuous). The best provenances (with less tortuous individuals) were the two of $E$. benthamii. Of the total number of individuals (89), nine were categorized as slightly tortuous only. Among the nine individuals, eight belonged to the population Santa Catarina Papel e Celulose. In general, the four provenances of $E$. smithii presented considerable number of tortuous or slightly tortuous individuals. Of the total, $44(37 \%)$ individuals presented slightly tortuous trunk, and 36 (31\%) individuals were categorized as type 3 (tortuous).

To further explore the variability of the species and provenances for the traits, we decomposed the genetic variance components for estimating the levels of genetic divergence among species and provenances (Table 3). For $D B H, H, V O L$ and bifurcation, most of the genetic variation was found within the provenances $\left(Q_{d}\right.$ varied from 63.6 to $73.1 \%)$. The level of genetic divergence between $E$. benthamii and E. smithii was high only for tortuosity $\left(Q_{\text {st }}\right.$ $=81.9 \%)$, which could be expected since E. benthamii presented almost no tortuous trees, while the $E$. smithii provenances varied considerably for the trait.

\section{Genetic mean and variance components with REML/BLUP}

The genetic analysis with REML/BLUP showed that both $E$. benthamii and E. smithii provenances presented genetic variation for $D B H, H, V O L$ and straightness. A comparison between $E$. benthamii and $E$. smithii revealed the latter had higher genetic variation for each one of the traits (Table 4), which could be associated to the higher number of provenances examined for $E$. smithii, therefore, allowing to discover more variation than with only two provenances of $E$. benthamii. The genotypic variation of $E$. smithii provevances for $D B H$ was approximately 16 times higher than of E. benthamii. For instance, the genotypic variation for $H$ was around 2.3 times higher in E. smithii provenances than E. benthamii, similar value of the volume (Table 4).

The genetic control of $\mathrm{DBH}, \mathrm{H}$ and $\mathrm{VOL}$ was estimated from mean heritabilities $\left(h_{m p}^{2}\right)$ of the provenances. E. benthamii provenances presented lower heritabilities for $\mathrm{DBH}, \mathrm{H}$ and $\mathrm{VOL}$ than E. smithii (Table 4). The heritabilities of $E$. benthamii varied from 0.11 to 0.31 , while for $E$. smithii the same variables presented $h_{m p}^{2}$ ranging from 0.65 to 0.69 . Such result suggested higher genetic control of the variables in E. smithii. It was highlighted by the calculation of the proximity between the estimated genetic value and the true genetic value, which is measured by the accuracy of selection $\left(A c_{\text {prov }}\right)$ (Table 4). The $A c_{\text {prov }}$ values varied from 0.33 to 0.56 for $E$. benthamii, while higher values ranging from $0.8 \mathrm{I}$ to 0.83 were detected for $E$. smithii for $D B H, H$ and VOL. Therefore, presumably higher gains from selection could be inferred from the E. smithii provenances, based on $A c_{\text {prov }}$.

The average heritability was only higher in $E$. benthamii $\left(h_{m p}^{2}=0.72 \mathrm{I}\right)$ than E. smithii $\left(h_{m p}^{2}=0.467\right)$ for straightness, also revealing similar results for the selection accuracy ( 0.85 and 0.68 , respectively) (Table 4). For instance, no estimates of genetic components
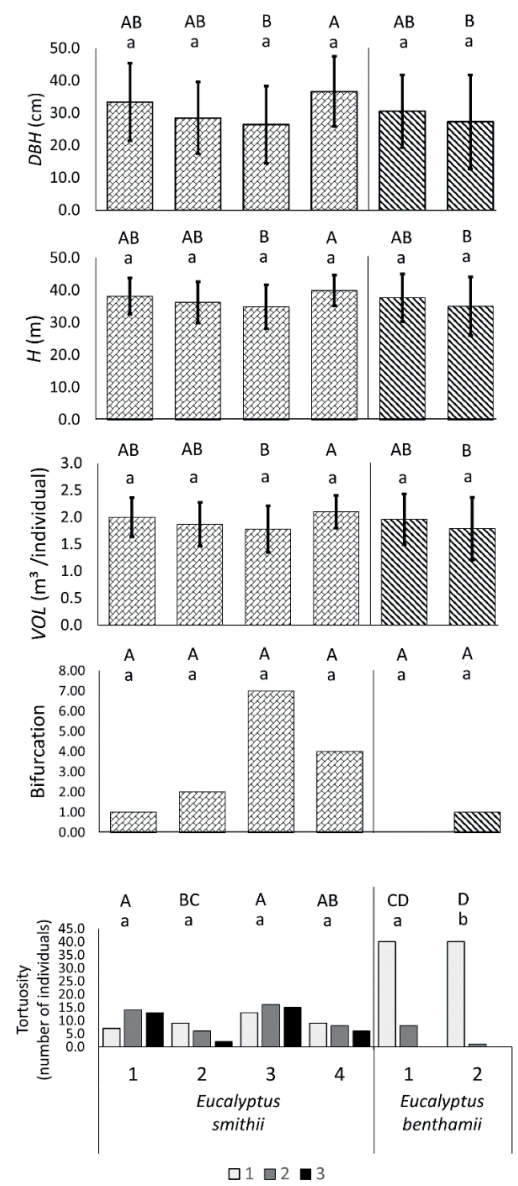

FIGURE I Average values of diameter at breast height $(D B H)$, height $(H)$ and volume (VOL), and frequencies of bifurcation and tortuosity in provenances of Eucalyptus smithii and $E$. benthamii. Bifurcation and tortuosity are represented by the number of individuals within each category of the variables. Bars indicate the standard deviation and were represented for the metric variables (DBH, H and VOL) only. E. smithii - I: Papel e Celulose Santa Catarina (P.C.C.-SC); 2: Taboaganda; 3: Australia; 4: Wilson Promontorj, Australia; E. benthamii: I: Papel e Celulose Santa Catarina (P.C.C.-SC); 2: Australia. Uppercase letters represent mean comparisons (Tukey's, $P<0.05$ ) among provenances from the joint analysis of the two species, while lowercase letters represent comparisons within each species. 
TABLE 4 Summary of genetic variance components for diameter at breast height $(D B H)$, height $(H)$, volume (VOL) and straightness (or level of tortuosity) of provenances* of E. benthamii and E. smithii installed in Southern Brazil.

\begin{tabular}{|c|c|c|c|c|c|c|c|c|}
\hline \multirow{2}{*}{$\begin{array}{c}\text { Genetic variance } \\
\text { components }\end{array}$} & \multicolumn{2}{|c|}{$\mathrm{DBH}$} & \multicolumn{2}{|c|}{$H$} & \multicolumn{2}{|c|}{ VOL } & \multicolumn{2}{|c|}{ Straightness } \\
\hline & E. benthamii & E. smithii & E. benthamii & E. smithii & E. benthamii & E. smithii & E. benthamii & E. smithii \\
\hline$V$ & $\mathrm{I} .0905$ & 17.1468 & 1.6305 & 3.7977 & 0.0068 & 0.0157 & 0.0111 & 0.0300 \\
\hline$V_{\text {blot }}^{g}$ & 23.8062 & 19.4066 & 9.7092 & 5.2431 & 0.0398 & 0.0215 & 0.0112 & 0.0885 \\
\hline$V_{e}^{\text {prot }}$ & 166.6434 & 135.8464 & $67.964 I$ & 36.7016 & 0.2785 & 0.1508 & 0.0786 & 0.6193 \\
\hline$V_{f}^{e}$ & $191.540 \mid$ & 172.3999 & 79.3038 & 45.7423 & 0.3250 & 0.1881 & 0.1009 & 0.7377 \\
\hline$h^{2}$ & 0.0057 & 0.0995 & 0.0206 & 0.0830 & 0.0208 & 0.0835 & 0.1099 & 0.0406 \\
\hline$c^{2}{ }_{p l o t}^{g}$ & 0.1243 & 0.1126 & 0.1224 & 0.1146 & 0.1224 & 0.1146 & 0.1113 & 0.1199 \\
\hline$h_{m p}^{2^{\text {plot }}}$ & 0.107 & 0.696 & 0.305 & 0.652 & 0.308 & 0.654 & 0.721 & 0.467 \\
\hline$A c_{\text {proc }}$ & 0.327289 & $0.834|2|$ & 0.552638 & $0.80755 I$ & 0.555288 & 0.808475 & 0.849231 & 0.683512 \\
\hline General mean & 29.03 & 31.19 & 34.46 & 37.28 & 1.88 & 1.94 & 1.09 & 1.95 \\
\hline
\end{tabular}

*The estimates were based on all individuals evaluated. $V_{g}$ : genetic variation among provenances; $V_{\text {plot }}$ : environmental variation among plots; $V_{e}$ : environmental variation among plots; $V_{f}$ individual phenotypic variance; $h_{g}{ }_{g}$ : determination coefficient of the effects of provenances; $C^{2}{ }_{\text {plot }}:$ determination coefficient of plot effect; $h^{2}{ }_{m p}:$ average heritability of provenances and $A c_{\text {prov }}$ : selection accuracy.

were obtained for bifurcation, as no significant variation has been observed for the trait in the populations.

Although presenting lower genetic variability, the analysis of $E$. benthamii provenances showed potential for selecting superior individuals, as revealed by BLUP analysis (Table 5). Overall, the best provenance of $E$. benthamii was Papel e Celulose Santa Catarina. The genetic gain from the selection of the population would be of $1.2 \%$ for $D B H$, I.8\% for $H$ and $2.2 \%$ for VOL. A Supplementary Table ST I is provided with details about the measurements of the individuals of each species and provenances.

Regarding E. smithii, higher genetic gains would be obtained for all variables than with $E$. benthamii (Table 5). The selection of provenance 4 (Wilson Promontorj, Australia) would increase the average values of $\mathrm{DBH}, \mathrm{H}$ and VOL in $13 \%, 5 \%$ and $6.1 \%$, respectively.

TABLE 5 Potential genetic gain (BLUP method) obtained from a species and provenance trial with Eucalyptus benthamii and Eucalyptus smithii in Southern Brazil.

\begin{tabular}{cccc}
\hline Species & Variable & Best provenance & Genetic gain (\%) \\
\hline \multirow{3}{*}{ E. benthamii } & $D B H$ & $\mathrm{I}$ & 1.2 \\
& $H$ & $\mathrm{I}$ & $\mathrm{I} .8$ \\
& $\mathrm{VOL}$ & $\mathrm{I}$ & 2.2 \\
\hline \multirow{3}{*}{ E. smithii } & $\mathrm{DBH}$ & 4 & 13.0 \\
& $H$ & 4 & 5.0 \\
& $V O L$ & 4 & 6.1 \\
\hline
\end{tabular}

$D B H$ : diameter at breast height; $H$ :height; $V O L$ : volume.

\section{DISCUSSION}

E. grandis and E. urophylla have prevailed in national and international markets due to their high productivity, especially in Brazil (FONSECA et al., 20 I0). However, breeders constantly seek novel alternatives for introducing new potential species, especially for certain areas in that they might not be so well adapted. In the case of Southern Brazil, as well as other subtropical regions, $E$. smithii and $E$. benthamii figure as suitable alternatives for large-scale plantations, as such species are originated from similar climates in Australia (MITCHELL et al., 20 I 2; BUTCHER et al., 2005). Our evaluation showed the potential of provenances of $E$. smithii and $E$. benthamii for breeding programs in Southern Brazil, which does not exclude them from being tested in other areas as well.

The ANOVA showed phenotypic variability for all the traits examined. A deeper examination of the genetic variance components and their hierarchic partition within and among species and provenances showed that most of the genetic divergence was found within the provenances for $D B H, H, V O L$ and bifurcation. This pattern is similar to the reported for various forest tree species for growth variables. In a comparison among provenances of Pinus maximinoi, Pinus oocarpa and $P$. tecunumanii, approximately $98 \%$ of the genetic divergence for $\mathrm{DBH}$ and VOL was found within the provenances, while more than $80 \%$ was found within provenances for $H$ (SOUZA et al., 2016). In provenances of Araucaria angustifolia, no more than $15 \%$ of the genetic divergence was found among the provenances, implicating that most diversity was distributed within them (SEBBENN et al. 2004). Moreover, a molecular study with microsatellite markers in natural populations of $E$. benthamii showed low genetic divergence among the populations, as indicated by the analogous parameter $F_{S T}$ (ranged from $7.8 \%$ to $15.7 \%$ ) (BUTCHER et al., 2005).

Although the type of experiment evaluated in this work might implicate in certain bias for a deeper investigation of the genetic variance components and genetic gains with REML/BLUP, the detection of genetic diversity among and within the species and provenances of this study suggested the possibility of estimating heritabilities and predicting potential genetic gains. Moreover, the genetic analysis of the present study revealed that the traits evaluated present similar genetic control to other reports in literature. Considerable research has shown variable heritability coefficients with Eucalyptus species. A compilation of open-pollinated trials with $E$. nitens has shown mean values of $h^{2}$ of 0.26 for $D B H, 0.23$ for $H$ and 0.39 por VOL (HAMILTON 
and POTTS, 2008). Progenies of distinct provenances of $E$. badjensis revealed heritabilities of $0.44,0.31$ and 0.358 , respectively for $D B H, H$ and VOL (SANTOS et al., 20I5). The evaluation of 30 clones of $E$. globulus showed heritability of 0.37 for diameter of the basal region of the trunk, 0.6 for $\mathrm{H}$ and 0.12 for VOL (SCHMIT et al., 20I5). Another study, for instance, with half-sib progenies of $E$. tereticornis, revealed broad-sense heritability estimates of $0.31,0.30$ and 0.21 , respectively, for $\mathrm{DBH}, \mathrm{H}$ and VOL (MACEDO et al., 20I3). In the case of $E$. benthamii, a recent study has demonstrated the genetic potential of selecting progenies for VOL, as an average heritability among progenies of 0.61 was found (COSTA et al., 2016). Although no direct comparison among the data of this work and the aforementioned studies is viable, we showed the possibility of selecting genetic materials from the $E$. benthamii and $E$. smithii provenances based on the premise of genetic variability existence, as also did these other studies.

The analysis of variance showed no intraspecific differences $(P<0.05)$ for diameter at breast height, height, volume and bifurcation. On the contrary, the $E$. benthamii populations contrasted for straightness. The provenance from Australia presented almost no tortuosity, while Santa Catarina Papel e Celulose presented slightly tortuous trunks in more individuals. However, E. smithii presented various tortuous trunks, which reflect against their selection in breeding programs, especially for highquality wood for industry processing (paper, cellulose, furniture, etc.). Therefore, considering bifurcation and tortuosity of the two species, the selection for a breeding program would be in favor of $E$. benthamii.

Nevertheless, an analysis of the genetic variance components as well as the mean components showed higher mean heritability $\left(h_{m p}^{2}\right)$ for $D B H, H$ and VOL in $E$. smithii provenances than of $E$. benthamii. The higher number of provenances and genetic variability of $E$. smithii influenced the values of such variables.

The genetic control of $E$. smithii revealed to be higher (based on broad-sense heritabilities) for all the variables analyzed. Moreover, the selection of E. smithii individuals could improve each variable with higher genetic gains than with $E$. benthamii. The selection of $E$. smithii, however, should take in account if the superior individuals and provenances of $E$. smithii for $\mathrm{DBH}, \mathrm{H}$ and VOL present less tortuous trunks.

Despite the cultivation of $E$. benthamii is more recent in Brazil and remains insipient and with skeptic view from producers, the selection of individuals from the provenances (especially Santa Catarina Papel e Celulose), according to BLUP, would implicate in considerable genetic gains as well. $E$. benthamii, therefore, holds potential for the development of breeding programs in Southern Brazil, applicable not only for energy, but also for improvement of wood quality and, therefore, for various other applications.

Another important observation from the data concerns the provenances of Australia of both species. For instance, comparing the two provenances of $E$. benthamii, the Australian provenance was probably constituted of more diverse and wild genetic materials, while Santa Catarina Papel e Celulose is at some level of breeding, therefore, resulting in higher predicted genetic gains from the latter. However, the provenance from Australia should not be neglected as more genetic variability might be found in wild populations, which could be useful in controlled crosses for breeding programs.

Our results provide insights for the development of further strategies aimed at detailed genetic characterization and breeding of $E$. smithii and $E$. benthamii. The selected individuals from this study might be used in progeny trials to extract additive genetic components and, therefore, improve the genetic control of the traits under investigation.

\section{CONCLUSIONS}

The evaluation of $E$. smithii and $E$. benthamii provenances located in Southern Brazil revealed considerable genetic variation for diameter at breast height, height, volume and straightness. In general, most of the variation was found within the provenances, except for straightness. Reasonably high heritability values were encountered from REML analysis, showing the possibility of genetic control of these traits in the populations examined. Moreover, it implicated in the prediction of considerable genetic gains from the two species, especially with $E$. smithii. Superior genotypes selected from the provenances might be used for further progeny trials, with potential of improving the genetic materials investigated.

\section{REFERENCES}

ABRAF 20I3. Anuário Estatístico ABRAF 20I3, ano base 2012. Brasília, 2013. I48 p.

ALMEIDA AZEVEDO, L. P. de.; COSTA, R. B.; MARTINEZ, D. T.; TSUKAMOTO-FILHO, A. A.; BRONDANI, G. E.; BARETTA, M. C.; AJALA, W. V. Seleção genética em progênies de Eucalyptus camaldulensis em área de cerrado matogrossense. Ciência Rural, v. 45, n. I I, p. 200I-2006, 2015.

ALVARES, C. A.; STAPE, J. L.; SENTELHAS, P. C.; DE MORAES, G.; LEONARDO, J.; SPAROVEK, G. Köppen's climate classification map for Brazil. Meteorologische Zeitschrift, v. 22, n. 6, p. 7II-728, 2013. 
BACCARIN, F. J. B.; BRONDANI, G. E.; DE ALMEIDA, L. V.; VIEIRA, I. G.; DE OLIVEIRA, L. S.; ALMEIDA, M. Vegetative rescue and cloning of Eucalyptus benthamii selected adult trees. New Forests, v. 46, n. 4, p. 465-483, 2015.

BENSON, D. H. Aspects of the ecology of a rare tree species, Eucalyptus benthamii, at Bents Basin, Wallacia. Cunninghamia, v. I, n. 3, p. 37I-383, 1985.

BOLAND, D.J.; BROPHY, J.J.; HOUSE, A.P.N. Eucalyptus leaf oils: use, chemistry, distillation and marketing. Melbourne: Inkata, 1992. 252 p.

BUTCHER, P. A.; SKINNER, A. K.; GARDINER, C. A. Increased inbreeding and inter-species gene flow in remnant populations of the rare Eucalyptus benthamii. Conservation Genetics, v. 6, n. 2, p. 213-226, 2005.

COSTA, R. M. L. da; ESTOPA, R. A; BIERNASKI, F. A.; MORI, E. S. Predição de ganhos genéticos em progênies de Eucalyptus benthamii Maiden \& Cambage por diferentes métodos de seleção. Scientia Forestalis, v. 44, n. 109, p. I05-II3, 2016.

EPAGRI SC S.A. - EPAGRI / CENTRO DE INFORMAÇÕES DE RECURSOS AMBIENTAIS E DE HIDROMETEOROLOGIA DE SANTA CATARINA - CIRAM. Zoneamento Agroecológico, 2009. Available at: <http://ciram.epagri. rct- sc.br/portal/website/index.jsp?url=jsp/agricultura/ zoneAgroecologico.jsp\&tipo=agricultura $>$.

ENGEL, M. L., HIGA, A. R., ANDREJOW, G. P., FLÔRES JUNIOR, P. C., SOARES, I. D. Genetic gain from different selection methods in Eucalyptus macarthurii progenies in different environments. Cerne, v. 22, n. 3, p. 299-308, 2016.

FONSECA, S. M. D. F.; RESENDE, M. D. V.; ALFENAS, A. C.; GUIMARÃES, L. M. DA S.; GRATTAPAGLIA, D. Manual prático de melhoramento genético de eucalipto. Viçosa: Ed. UFV, 2010. 200 p.

HAMILTON, M. G.; POTTS, B. M. Eucalyptus nitens genetic parameters. New Zealand Journal of Forestry Science, v. 38, n. I, p. I02-I 19, 2008.

IBÁ - Indústria Brasileira de Árvores. Dados e estatísticas. 2016 Available at: <http://iba.org/images/shared/Biblioteca/IBA RelatorioAnual2016_pdf $>$

MACEDO, H. R.; FREITAS, M. L. M.; DE MORAES, M. L. T.; ZANATA, M.; SEBBEN, A. M. Variation, heritability and genetic gain in progeny of Eucalyptus tereticornis at 25 years of age in Batatais-SP. Scientia Forestalis, v. 4I, n. I00, p. 533-540, 2013.

MITCHELL, P. J.; O'GRADY, A. P.; TISSUE, D. T.; WHITE, D. A.; OTTENSCHLAEGER, M. L.; PINKARD, E. A. Drought response strategies define the relative contributions of hydraulic dysfunction and carbohydrate depletion during tree mortality. New Phytologist, v. 197, n. 3, p. 862-872, 2012.
MORA, A. L.; GARCIA, C. H. A cultura do eucalipto no Brasil. Sociedade Brasileira de Silvicultura, 2000. I 12 p.

MORI, E. S.; KAGEYAMA, P. Y.; FERREIRA, M. Variação genética e interação progênies $\mathrm{x}$ locais em Eucalyptus urophylla. Revista do IPEF, v. 39, p. 53-63, 1988.

ODA, S.; MELLO, E. J. de; SILVA, J. F. da; SOUZA, I. C. G. de. Melhoramento florestal. In: BORÉM, A. (Ed.) Biotecnologia florestal, Viçosa: UFV, 2007. p. |23-| 42.

RESENDE, M. D. V. de. Selegen-Reml/Blup: sistema estatístico e seleção genética computadorizada via modelos lineares mistos. Embrapa Florestas, 2007, 359p.

ROCHA, R. B.; MURO-ABAD, J. I.; ARAÚJO, E. F.; CRUZ, C. D. Avaliação do método centróide para estudo de adaptabilidade ao ambiente de clones de Eucalyptus grandis. Ciência Florestal, v. I5, n. 3, p. 255-266, 2005.

SANTOS, P. E. T.; GARCIA, C. H.; MORI, E. S.; MORAES, M. L. T. Potencial para programas de melhoramento, estimativas de parâmetros genéticos e interação progênies x locais em populações de Eucalyptus urophylla ST Blake, 1990. IPEF, n. 43/44, p. II-19, 1990.

SANTOS, P. E. T. D.; PALUDZYSZYN FILHO, E.; SILVA, L. T. D. M. D.; VANDRESEN, P. B. Genetic variation for growth and selection in adult plants of Eucalyptus badjensis. Genetics and Molecular Biology, v. 38, n. 4, p. 457-464, 2015.

SANTOS, G. A.; NUNES, A. C. P.; RESENDE, M. D. V.; SILVA, L. D.; HIGA, A.; ASSIS, T. F. Genetic control and genotypeby-environment interaction of wood weight in Eucalyptus clones in the state of Rio Grande do Sul, Brasil. Revista Árvore, v. 40, n. 5, p. 867-876, 2016.

SCHMIT, R.; MORA, F.; EMHART, V. I.; RUBILAR, R. Longitudinal analysis in the selection of Eucalyptus globulus clones under contrasting water availability conditions. Scientia Forestalis, v. 43, n. I05, p. 217-224, 2015.

SEbBENN, A. M., PONTINHA, A. D. A. S., Freitas, S. A., \& Freitas, J. A. Variação genética em cinco procedências de Araucaria angustifolia (Bert.) $O$. Ktze. no sul do Estado de São Paulo. Revista do Instituto Florestal, v. 16, n. 2, p. 91-99, 2004.

SILVA, L. J. Package “laercio”. R Developmental Core Team, 2015.

SOUZA, F. B., FREITAS, M. L. M., MORAES, M. L. T., BOAS, O. V.; SEBBENN, A. M. Seleção de espécies e procedências de Pinus para região de Assis, Estado de São Paulo. Scientia Forestalis, v. 44, n. III, p. 675-682, 2016.

WEGNAR, P. Z. Caracterização dos Recursos Naturais e Uso do Solo da Área de Proteção Ambiental da Represa do Alto Rio Preto, Rio Negrinho - SC.2000. 175 f. Dissertação (Mestrado em Engenharia Ambiental). Universidade Federal de Santa Catarina. Florianópolis, 2000. 